\title{
Urea coated with poultry litter as an option in the control of nitrogen losses
}

\author{
Daniel J. Dall'Orsoletta ${ }^{1}$, Luiz P. Rauber ${ }^{2}$, Djalma E. Schmitt ${ }^{1}$, Luciano C. Gatiboni ${ }^{1}$ \& Jhonatan Orsolin ${ }^{3}$ \\ ${ }^{1}$ Universidade do Estado de Santa Catarina/Centro de Ciências Agroveterinárias. Lages, SC. E-mail: dani.orsoletta@gmail.com (Corresponding author); \\ djalma.schmitt@yahoo.com.br; lgatiboni@gmail.com \\ ${ }^{2}$ Universidade do Oeste de Santa Catarina. Campo Novos, SC. E-mail: sr_roiber@yahoo.com.br \\ ${ }^{3}$ Monsanto Brasil. Palmitos, SC. E-mail: jhona_orsolin@hotmail.com
}

\section{Key words:}

volatilization

nitrification

mineral nitrogen

\begin{abstract}
A B S T R A C T
The volatilization of ammonia $\left(\mathrm{NH}_{3}\right)$ and nitrate leaching $\left(\mathrm{NO}_{3}^{-}\right)$are the main processes of nitrogen $(\mathrm{N})$ loss in the soil. The objective of the study was to evaluate $\mathrm{N}$ losses by $\mathrm{NH}_{3}$ volatilization and mineral $\mathrm{N}$ transformations in the soil with urea coated with poultry litter (urea + litter) compared with other sources of $\mathrm{N}$, under two moisture conditions. The experiment was conducted in a controlled environment with a $5 \times 2$ factorial arrangement with four replicates, five $\mathrm{N}$ sources (urea, SuperN ${ }^{\circ}$, Kimcoat ${ }^{\circ}$, urea + litter and control without fertilizer) and two moisture contents [ 80 and $100 \%$ of field capacity (FC)]. The total volatilized $\mathrm{NH}_{3}$ did not differ between the sources, regardless of the soil moisture condition, ranging from 10.8 to $13.2 \%$ of the total $\mathrm{N}$ applied. The transformation of $\mathrm{NH}_{4}^{+}$ into $\mathrm{NO}_{3}$ - did not vary between the sources, except for the control, but it differed between soil moisture contents, with equilibrium estimated at 31 and 38 days, in the treatments

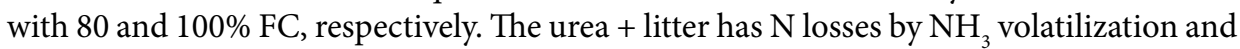
speed of transformation of the soil mineral $\mathrm{N}$ similar to those of the other sources, and can be used to substitute them.
\end{abstract}

Palavras-chave:

volatilização

nitrificação

nitrogênio mineral

\section{Ureia recoberta com cama de aviário como opção no controle de perdas de nitrogênio}

\begin{abstract}
R E S U M O
A volatilização de amônia $\left(\mathrm{NH}_{3}\right)$ e lixiviação de nitrato $\left(\mathrm{NO}_{3}^{-}\right)$são os principais processos de perda de nitrogênio $(\mathrm{N})$ no solo. $\mathrm{O}$ objetivo do estudo foi avaliar perdas de $\mathrm{N}$ por volatilização de $\mathrm{NH}_{3}$ e as transformações do $\mathrm{N}$ mineral no solo com ureia recoberta com cama de aviário (ureia + cama) comparativamente a outras fontes de $\mathrm{N}$, em duas condições de umidade. $O$ experimento foi conduzido em ambiente controlado com arranjo fatorial $5 \mathrm{x}$ 2 com quatro repetições sendo cinco fontes de N (ureia, SuperN ${ }^{\circledR}$, Kimcoat ${ }^{\circledast}$, ureia + cama e testemunha sem fertilizante) e dois teores de umidade [80 e 100\% da capacidade de campo (CC)]. O total de $\mathrm{NH}_{3}$ volatilizada não diferiu entre as fontes independente da condição de umidade do solo variando de 10,8 a $13,2 \%$ do total de $\mathrm{N}$ aplicado. A transformação do $\mathrm{NH}_{4}^{+}$em $\mathrm{NO}_{3}^{-}$não variou entre as fontes, exceto a testemunha mas diferiu entre as umidades do solo com equilíbrio estimado aos 31 e 38 dias, nos tratamentos com 80 e $100 \%$ $\mathrm{CC}$, respectivamente. A ureia + cama apresenta perdas de $\mathrm{N}$ por volatilização de $\mathrm{NH}_{3}$ e velocidade de transformação do $\mathrm{N}$ mineral do solo semelhante às demais fontes podendo ser utilizada em substituição a essas.
\end{abstract}




\section{INTRODUCTION}

The low efficiency of nitrogen $(\mathrm{N})$ fertilizations can be attributed to the $\mathrm{N}$ losses through the emission of gases and leaching and reflects in the loss of yield of the crops and causes deleterious effects on the environment (Cantarella et al., 2008; Li et al., 2014). The leaching of nitrate $\left(\mathrm{NO}_{3}^{-}\right)$favors the eutrophication of aquatic environments, while the ammonia gas $\left(\mathrm{NH}_{3}\right)$ is toxic to most living organisms (Asing \& Verma, 2008; Cameron et al., 2013; Singh et al., 2013). However, environmental factors such as humidity, temperature and $\mathrm{pH}$ can have an influence on the magnitude of $\mathrm{N}$ losses (Rochette et al., 2009; Tasca et al., 2011; Li et al., 2014).

Some techniques maximize the efficiency of $\mathrm{N}$ fertilization (Zhang et al., 2015), especially the addition of urease inhibitors such as $\mathrm{N}$-(n-butyl)thiophosphoric triamide (NBPT) and the coating of $\mathrm{N}$ fertilizers with polymers, resins and gypsum (Sanz-Cobeña et al., 2012; Halvorson et al., 2014). These processes aim to reduce the solubility of the fertilizer generating a gradual release of the nutrient to the soil, in a controlled way and with a possible synchrony with the needs of the crops (Azeem et al., 2014). On the other hand, many products have high costs and are not biodegradable and thus can have toxic action (Al-zahrani, 2000; Azeem et al., 2014). Hence, the utilization of organic materials to coat $\mathrm{N}$ fertilizers, such as poultry litter, must be evaluated.

Therefore, this study aimed to evaluate the efficiency of urea coated with poultry litter regarding the susceptibility to $\mathrm{N}$ losses through $\mathrm{NH}_{3}$ volatilization and speed of transformation of $\mathrm{NH}_{4}{ }^{+}$into $\mathrm{NO}_{3}{ }^{-}$, under two soil moisture conditions.

\section{Material AND Methods}

This study comprised two experiments conducted in the laboratory in 2013. Initially, a Humic Cambisol (EMBRAPA, 2013) with clayey texture was sampled in the layer of $0-20 \mathrm{~cm}$ and showed the following chemical and physical attributes: Clay - $455 \mathrm{~g} \mathrm{~kg}^{-1}$ (EMBRAPA, 2011), organic matter - $46 \mathrm{~g}$ $\mathrm{kg}^{-1}, \mathrm{pH}_{-\mathrm{H} 2 \mathrm{O}}-5.4, \mathrm{pH}_{\mathrm{SMP}^{-}}-5.9, \mathrm{Al}^{3+}, \mathrm{Ca}^{2+}, \mathrm{Mg}^{2+}$ and $\mathrm{CEC}-1.5$, 5.6, 1.9 and $12.7 \mathrm{cmol}_{\mathrm{c}} \mathrm{dm}^{-3}$ respectively; available $\mathrm{P}$ and $\mathrm{K}$ 3.1 and $92 \mathrm{mg} \mathrm{dm}^{-3}$, respectively, and base saturation - 61\% (Tedesco et al., 1995).

The soil, after dried, passed through a 2-mm-mesh sieve and was incubated with dolomitic limestone with recommendation for $\mathrm{pH}$ 6.0 (CQFS-RS/SC, 2004) for 30 days, until reaching the desired $\mathrm{pH}$. Both experiments were set in a completely randomized design with samples repeated over time, in a $5 \mathrm{x}$ 2 factorial scheme with four replicates, corresponding to four amidic $\mathrm{N}$ sources: Urea, Kimcoat', SuperN", urea coated with poultry litter (urea + litter), with $45,43,44$ and $30 \%$ of $\mathrm{N}$ and one control without fertilizer application, and two moisture contents: 0.39 and $0.49 \mathrm{~cm}^{3} \mathrm{~cm}^{-3}$, corresponding to 80 and $100 \%$ of field capacity (FC), respectively.

In both experiments, the soil received the same $\mathrm{N}$ dose of $100 \mathrm{mg} \mathrm{kg}^{-1}$, equivalent to $200 \mathrm{~kg} \mathrm{ha}^{-1}$ of $\mathrm{N}$, regardless of the source, except the control, using as the base of calculation the surface area of the experimental unit in which the fertilizers were homogeneously distributed. Soil moisture was maintained according to the treatment 80 or $100 \%$ FC, through the replacement of the water lost, measured by weighing the experimental units and adding distilled water.

The experiment 1 evaluated the effect of the application of five $\mathrm{N}$ sources in the soil and two moisture contents on the $\mathrm{N}$ losses through $\mathrm{NH}_{3}$ volatilization, in eight sampling periods, at 2, 4, 6, 8, $10,15,23$ and 28 days after applying the treatments (DAA). The experimental units consisted of plastic pots with capacity for 0.7 L containing $0.3 \mathrm{~kg}$ of soil and a surface area of $42.7 \mathrm{~cm}^{2}$.

The volatilized $\mathrm{NH}_{3}$ was captured in Falcon tubes with capacity for $15 \mathrm{~mL}$, containing $10 \mathrm{~mL}$ of $0.17 \mathrm{~mol} \mathrm{~L}^{-1} \mathrm{H}_{3} \mathrm{PO}_{4}$ with glycerin (1\%) and two strips filter paper $(1 \times 8 \mathrm{~cm})$ immersed in this solution to increase the contact surface of the $\mathrm{NH}_{3}$ with the $\mathrm{H}_{3} \mathrm{PO}_{4}$. The tube containing the solution to capture $\mathrm{NH}_{3}$ was fixed in the soil at the moment of application of the treatments, substituted in each sampling and taken to the laboratory for analysis. The volatilized $\mathrm{NH}_{3}$ was quantified by the steam distillation of the capturing solution plus the strips of filter paper in a micro-Kjeldahl apparatus after alkalinization with $10 \mathrm{~mol} \mathrm{~L}^{-1} \mathrm{NaOH}$ (Tedesco et al., 1995).

The experiment 2 evaluated the effects of the same treatments of the experiment 1 on the transformation of soil mineral $\mathrm{N}\left(\mathrm{NH}_{4}^{+}\right.$and $\left.\mathrm{NO}_{3}{ }^{-}\right)$, in six sampling periods, at 0,5 , $10,15,23$ and 28 DAA. The experimental units consisted of plastic pots with capacity for $1 \mathrm{~L}$ containing $0.7 \mathrm{~kg}$ of soil and surface area of $49.5 \mathrm{~cm}^{2}$.

The soil was sampled in each period using a $1-\mathrm{cm}$-diameter plastic cylinder, which was inserted in the soil until touching the bottom of the pot and carefully removed in order not to disturb the surroundings. The mineral- $\mathrm{N}$ was determined on the same day of sampling, extracted with $1.0 \mathrm{~mol} \mathrm{~L}^{-1}$ $\mathrm{KCl}$ solution, collecting an aliquot for later distillation and determination of $\mathrm{N}$ in semimicro-Kjeldahl apparatus, for the quantification of $\mathrm{NH}_{4}-\mathrm{N}$ and $\mathrm{NO}_{3}-\mathrm{N}$ (Tedesco et al., 1995).

The data obtained in both experiments were subjected to analysis of variance (ANOVA) and the sampling periods were analyzed as measurements repeated over time; the significant effects, when qualitative (sources and moisture), were compared by the Tukey test of means of $(p<0.05)$ and, when quantitative (days), by the fitting of regression curves, using the statistical programs Sisvar 5.6 (Ferreira, 2014) and SigmaPlot 12.5 , respectively.

\section{Results AND Discussion}

\section{Experiment 1. Ammonia volatilization of different $\mathrm{N}$ sources under two soil moisture conditions, in various periods after application}

The soil moisture condition did not interfere with the $\mathrm{N}$ losses through $\mathrm{NH}_{3}$ volatilization (Figure 1). The SuperN" led to lower mean volatilization of $\mathrm{NH}_{3}-\mathrm{N}$ until the 23 days, due to the decrease in the release of $\mathrm{NH}_{4}-\mathrm{N}$ from the fertilizer by the inhibition of the urease enzyme. However, this decrease in urease activity is observed only for an initial period, although there was, at the end of the experiment, difference between the treatments evaluated under the different conditions of soil moisture. The mean $\mathrm{N}$ losses at 28 DAA were 11.4 and $12.1 \%$ of the total applied, for the moisture contents of 80 and $100 \%$ FC, respectively. 


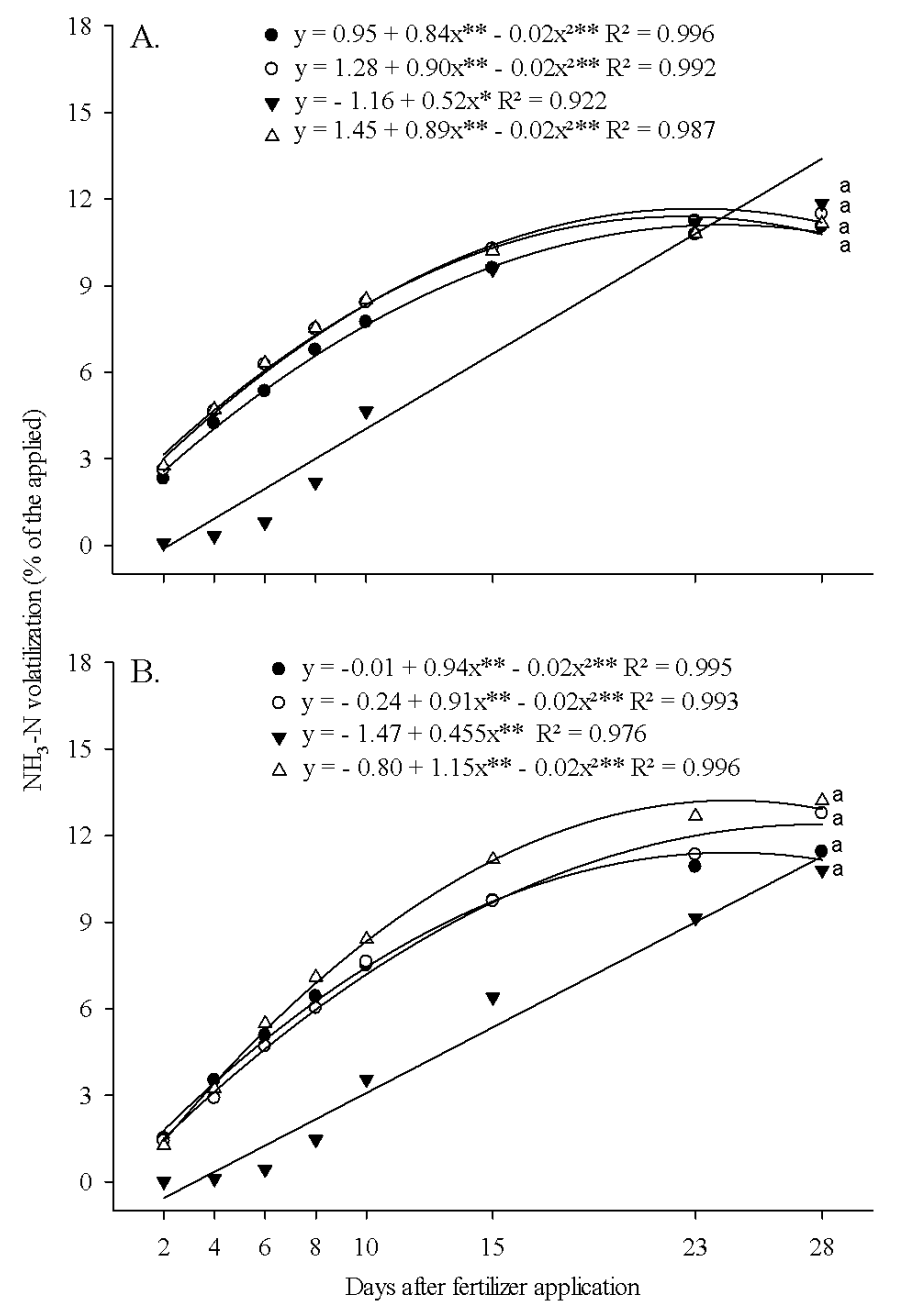

Sources followed by same letters do not differ by Tukey test $(p<0.05)$; ${ }^{*}$ Significant $p<$ $0.05 ;{ }^{* *}$ Significant $p<0.01$

Figure 1. Ammonia volatilization from the soil in percentage of the applied after application of $100 \mathrm{mg} \mathrm{kg}^{-1}$ of $\mathrm{N}$ in the form of urea $(\bullet)$, Kimcoat ${ }^{\oplus}(\mathrm{O})$, Super $\mathrm{N}(\boldsymbol{\nabla})$ and urea $+\operatorname{litter}(\Delta)$ at the soil moistures of $80(A)$ and $100 \%$ (B) of field capacity, subtracting the values of the control

At the soil moisture of $100 \%$ FC for urea + litter, the relative loss was $13.2 \%$ of the total $\mathrm{N}$ applied, but without differing from the other sources, which evidences that the coating of urea with poultry litter did not have effects on the $\mathrm{N}$ losses through $\mathrm{NH}_{3}$ volatilization.

The daily losses of $\mathrm{NH}_{3}$ responded to the effects of the fertilizer and soil moisture in the intervals after application of the fertilizer (Figure 2). The daily losses of $\mathrm{N}$ through $\mathrm{NH}_{3}$ volatilization in the soil with moisture of $80 \%$ FC initially exceeded those of the soil with moisture of $100 \%$ FC, but with lower variation over time.

The peak of volatilization, except for SuperN ${ }^{*}$, which was recorded at $10 \mathrm{DAA}$, occurred at $2 \mathrm{DAA}$ for the other fertilizers at $80 \%$ FC. For this moisture condition, the daily $\mathrm{NH}_{3}$ volatilization was similar for all fertilizers at $28 \mathrm{DAA}$ and did not differ from the control. On the other hand, at the moisture of $100 \%$ FC the peak of volatilization occurred at 4 DAA for urea, 6 DAA for urea + litter and Kimcoat and at 10 DAA for SuperN; ${ }^{\circ}$ at 28 DAA, only urea and urea + litter did not differ from the control.

The utilization of urease inhibitors, such as the NBPT present in the SuperN", generally reduces the initial $\mathrm{NH}_{3}$

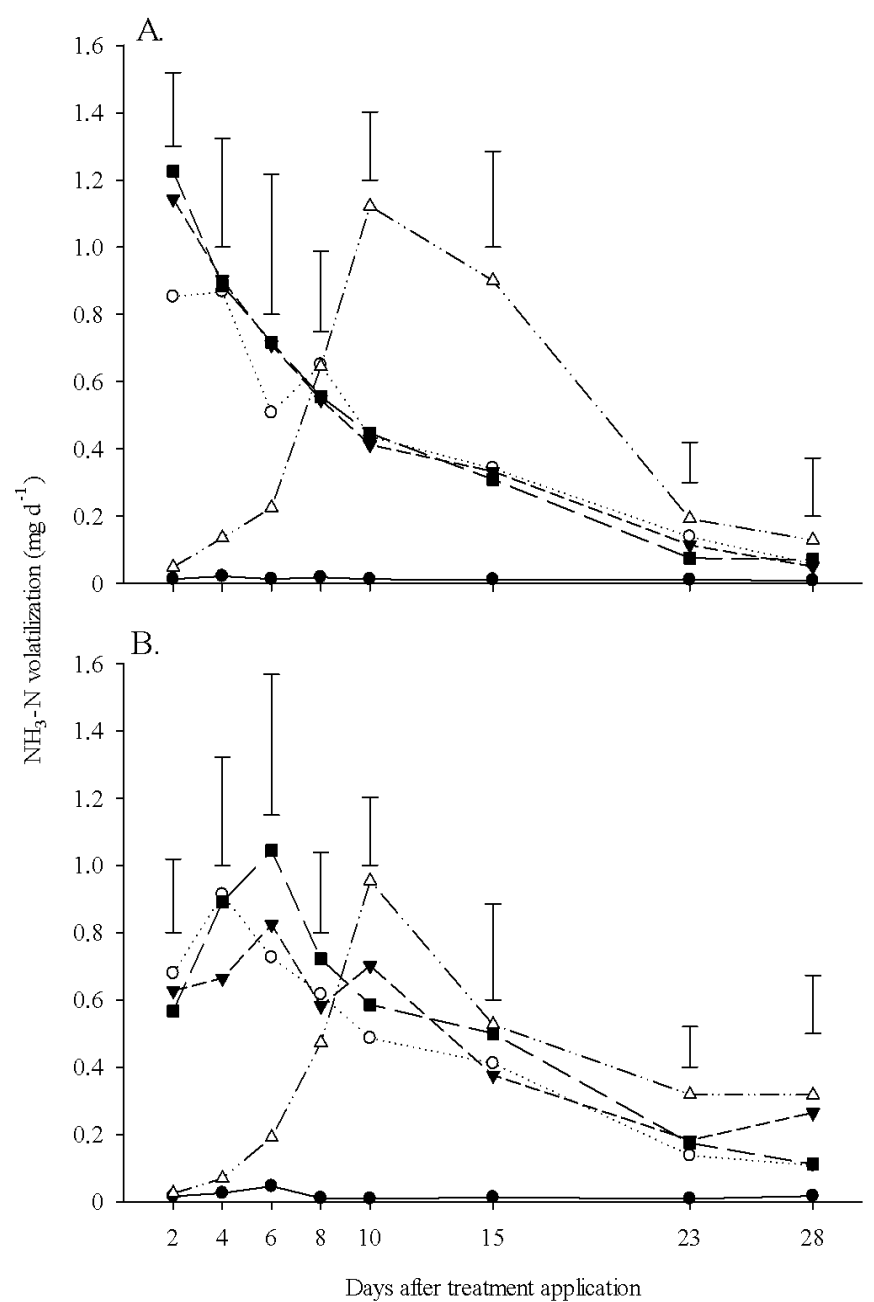

Bars represent the minimum significant difference between the sources in each period by Tukey test $(p<0.05)$

Figure 2. Daily volatilization of $\mathrm{NH}_{3}$ from the soil without $(\bullet)$ and with $100 \mathrm{mg} \mathrm{kg}^{-1}$ of $\mathrm{N}$ in the form of urea (o), Kimcoat $^{\oplus}(\boldsymbol{\nabla})$, SuperN $N^{\oplus}(\Delta)$, urea $+\operatorname{litter}(\boldsymbol{\square})$ at the moisture contents of 80 (A) and $100 \%$ (B) of field capacity

volatilization in relation to the conventional soluble fertilizers (Zaman \& Blennerhassett, 2010; Tasca et al., 2011; Li et al., 2014; Tian et al., 2015), in response to the inhibition of the hydrolysis of urea to $\mathrm{NH}_{4}-\mathrm{N}$ available to be converted to $\mathrm{NH}_{3}$. In addition, the higher soil moisture favors $\mathrm{NH}_{3}$ volatilization, due to the greater urease activity under high moisture conditions (Rochette et al., 2009), or reduces it, for favoring the diffusion of the urea molecule and also the mineralized $\mathrm{NH}_{4}^{+}$to the inside of the soil porous space (Li et al., 2014).

\section{Experiment 2. Transformation of the soil mineral- $\mathrm{N}$ from different $\mathrm{N}$ sources under two soil moisture conditions}

The $\mathrm{NH}_{4}^{+}$concentrations available in the soil were individually influenced by the sources (Figure 3A) and soil moisture (Figure 3B), but did not respond to the effects of interaction between both factors. For all fertilizers, the highest $\mathrm{NH}_{4}{ }^{+}$concentrations were observed at $15 \mathrm{DAA}$, while for the control these values did not differ over time, with mean of $53.3 \mathrm{mg} \mathrm{kg}^{-1}$. The $\mathrm{NH}_{4}{ }^{+}$concentration in the soil was very close between the fertilizers; however, the soil fertilized with urea + litter showed the highest $\mathrm{NH}_{4}^{+}$concentrations until $22 \mathrm{DAA}$, being surpassed by the SuperN ${ }^{\circ}$ at 28 DAA. 

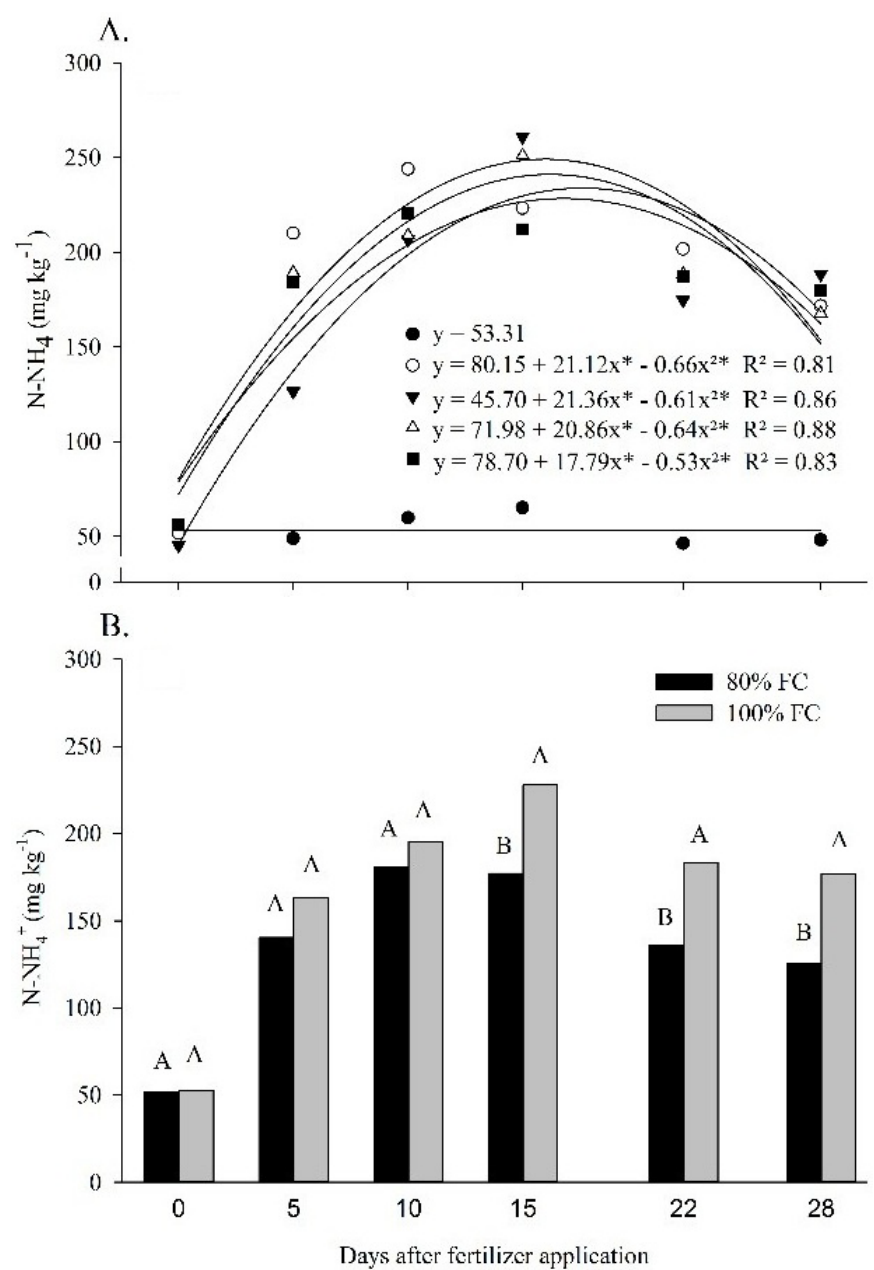

The same letters do not differ by Tukey test $(p<0.05)$; ${ }^{\text {Significant }} \mathrm{p}<0.05$; * Significant $\mathrm{p}<0.01$

Figure 3. Soil $\mathrm{NH}_{4}{ }^{+}$concentration along the time of application of $100 \mathrm{mg} \mathrm{kg}^{-1}$ of $\mathrm{N}(\mathrm{A})$ in the form of urea (O), $\operatorname{Kimcoat}^{\oplus}(\Delta)$, Super $N^{\circledast}(\boldsymbol{\nabla})$, urea + litter $(\boldsymbol{\square})$ and control, without fertilizer application $(\bullet)$, mean of two soil moisture conditions and soil $\mathrm{NH}_{4}{ }^{+}$concentration with application of $100 \mathrm{mg} \mathrm{kg}^{-1}$ of $\mathrm{N}$ at 80 and $100 \%$ of field capacity - FC (B)

The poultry litter, for being an organic product used to coat urea + litter, according to Bowles et al. (2014), has high concentration of enzymes such as urease and, thus, the urea molecules in the treatment urea + litter were rapidly hydrolyzed, releasing higher $\mathrm{NH}_{4}^{+}$concentrations since the beginning of the experimental period. On the other hand, the use of urease inhibitors such as NBPT, used in the SuperN", delayed the release of $\mathrm{NH}_{4}^{+}$in comparison to the other fertilizers until 10 DAA, which is similar to the results of $\mathrm{NH}_{3}$ fertilization of the experiment 1 (Figures 1 and 2).

The soil moisture also influenced the soil $\mathrm{NH}_{4}{ }^{+}$concentration over time (Figure 3). At $10 \mathrm{DAA}$, the treatments with moisture of $100 \%$ FC showed higher $\mathrm{NH}_{4}{ }^{+}$concentrations, probably because the lower availability of oxygen in this treatment limits the oxidation of $\mathrm{NH}_{4}-\mathrm{N}$ to $\mathrm{NO}_{3}-\mathrm{N}$ (Guo et al., 2014; Chen et al., 2015).

The soil $\mathrm{NO}_{3}$ - concentration was also influenced by the soil moisture and $\mathrm{N}$ sources applied, linearly increasing over time (Figure 4). In systems without leaching, as the studied one, most mineral- $\mathrm{N}$ is generally in the form of $\mathrm{NO}_{3}^{-}$, because the
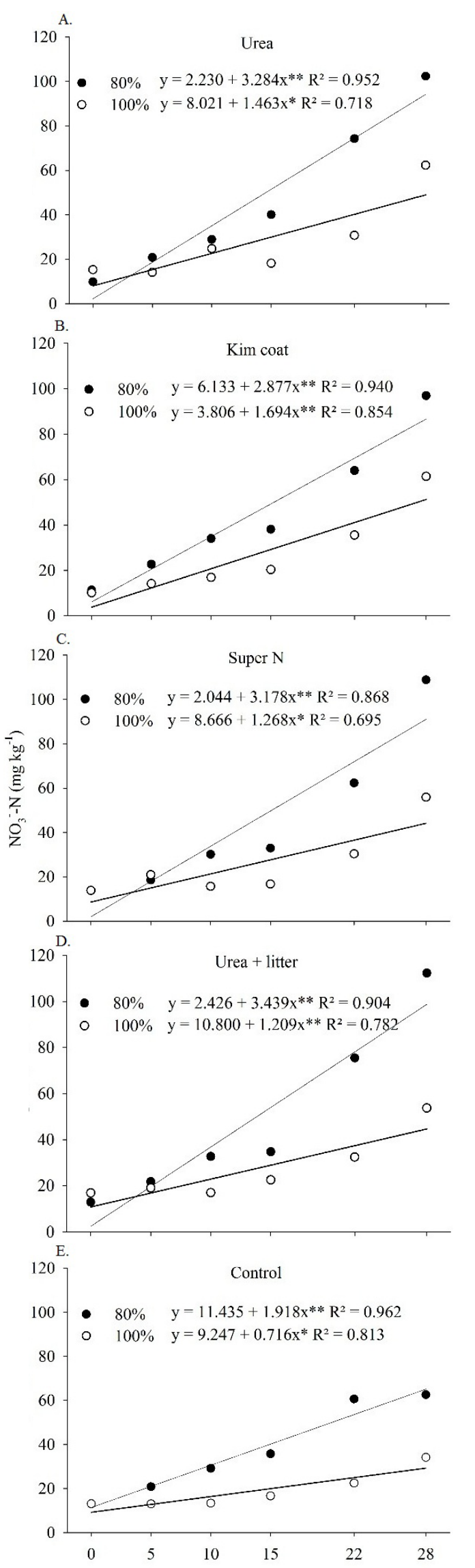

Days after treatment application

* Significant $\mathrm{p}<0.05 ; * *$ Significant $\mathrm{p}<0.01$

Figure $4 . \mathrm{NO}_{3}{ }^{-}$concentration of the soil along the time after application of $100 \mathrm{mg} \mathrm{kg}^{-1}$ of $\mathrm{N}$ in the form of urea, Kimcoat $^{\oplus}$, Super $N^{\circledast}$, urea + litter, under two soil moisture conditions ( 80 and $100 \%$ of field capacity - FC) 


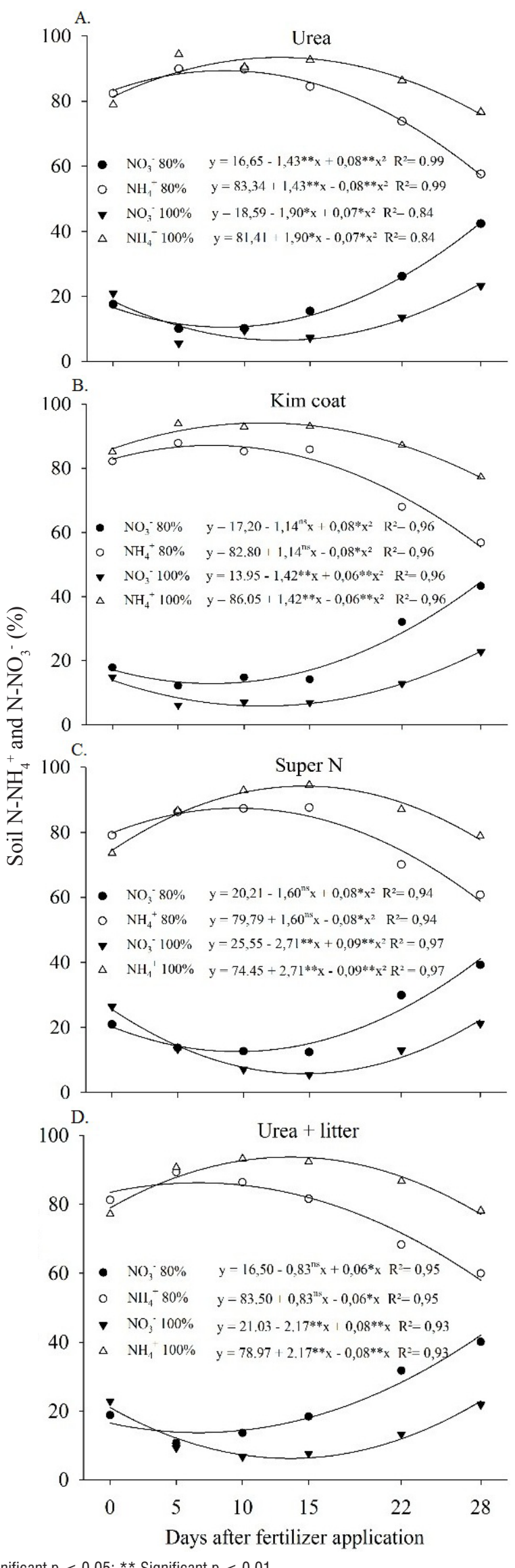

* Significant $p<0.05 ; * *$ Significant $p<0.01$

Figure 5. Percentage of total mineral- $\mathrm{N}$ of the soil in the forms of $\mathrm{NH}_{4}{ }^{+}$and $\mathrm{NO}_{3}{ }^{-}$along the time of application of $100 \mathrm{mg} \mathrm{kg}^{-1}$ of $\mathrm{N}$ in the form of urea, Kimcoat ${ }^{\circ}$, SuperN ${ }^{\circ}$, urea + litter, under two soil moisture conditions (80 and $100 \%$ FC) volatilization and oxidation consume the $\mathrm{NH}_{4}{ }^{+}$ions present in the soil, which are catalyzed by the microbial action (Bowles et al., 2014; Chen et al., 2015).

Given the above, the faster the nitrification of the applied fertilizer, the greater its susceptibility to losses through leaching, because the $\mathrm{NO}_{3}{ }_{3}^{-}$ions are not adsorbed to the superficial charges of the colloids (Zaman \& Blennerhassett, 2010). However, the evaluation period proved to be insufficient to reach the equilibrium between the amidic and nitric forms (Figure 5). Despite that temporal insufficiency, there was influence of soil moisture on the nitrification process, expressed by the lower availability of oxygen in the treatment of $100 \%$ FC, delaying the nitrification, with estimated mean of 38 days to reach the equilibrium between $\mathrm{NH}_{4}-\mathrm{N}$ and $\mathrm{NO}_{3}-\mathrm{N}$, and of 31 days in the treatments with $80 \% \mathrm{FC}$.

\section{Conclusions}

1. The urea coated with poultry litter did not influence nitrogen losses through ammonia volatilization, regardless of the soil moisture condition.

2. The highest soil moisture content reduced the speed of nitrification of the soil nitrogen.

3. The urea coated with poultry litter can be used in substitution to other amidic nitrogen sources, regardless of the soil moisture condition.

\section{Literature Cited}

Al-zahrani, S. M. Utilization of polyethylene and paraffin waxes as controlled delivery systems for different fertilizers. Industrial and Engineering Chemistry Research, v.39, p.367-371, 2000. https:// doi.org/10.1021/ie980683f

Asing, J.; Verma, A. Assessment of nitrogen losses from urea and garden galore with and without nitrification inhibitor, dicyandiamide applied to lettuce under glasshouse conditions. Australian Journal Soil Reseach, v.46, p.535-541, 2008. https://doi.org/10.1071/ SR07206

Azeem, B.; Kushaari, K.; Man, Z. B.; Basit, A.; Thanh, T. H. Review on materials \& methods to produce controlled release coated urea fertilizer. Journal of Controlled Release, v.181, p.11-21, 2014. http:// doi.org/10.1016/j.jconrel.2014.02.020

Bowles, T. M.; Acosta-martínez, V.; Calderón, F.; Jackson, L. E. Soil enzyme activities, microbial communities, and carbon and nitrogen availability in organic agroecosystems across an intensivelymanaged agricultural landscape. Soil Biology and Biochemistry, v.68, p.252-262, 2014. http://doi.org/10.1016/j.soilbio.2013.10.004

Cameron, K. C.; Di, H. J.; Moir, J. L. Nitrogen losses from the soil/plant system: A review. Annals of Applied Biology, v.162, p.154-173, 2013. http://doi.org/10.1111/aab.12014

Cantarella, H.; Trivelim, P. C. O.; Contin, T. L. M.; Dias, F. L. F.; Rossetto, R.; Marcelino, R.; Coimbra, R. B.; Quaggio, J. A. Ammonia volatilisation from urease inhibitor-treated urea applied to sugarcane trash blankets. Scientia Agricola, v.65, p.397-401, 2008. https://doi.org/10.1590/S0103-90162008000400011 
Chen, Z.; Ding, W.; Xu, Y.; Müller, C.; Rütting, T.; Yu, H.; Zhu, T. Importance of heterotrophic nitrification and dissimilatory nitrate reduction to ammonium in a cropland soil: Evidences from a $15 \mathrm{~N}$ tracing study to literature synthesis. Soil Biology and Biochemistry, v.91, p.65-75, 2015. http://doi.org/10.1016/j. soilbio.2015.08.026

CQFS-RS/SC - Comissão de química e fertilidade do solo - Manual de adubação e de calagem para os estados do Rio Grande do Sul e Santa Catarina. 10.ed. Porto Alegre: SBCS-Núcleo Regional Sul, 2004. 400p.

EMBRAPA - Empresa Brasileira de Pesquisa Agropecuária. Manual de métodos de análise de solo. 2.ed. Rio de Janeiro: Embrapa Solos, 2011.230p.

EMBRAPA - Empresa Brasileira de Pesquisa Agropecuária. Sistema brasileiro de classificação de solos. 3.ed. Brasília: Embrapa, 2013. $353 \mathrm{p}$.

Ferreira, D. F. Sisvar: A guide for its bootstrap procedures in multiple comparisons. Ciência e Agrotecnologia, v.38, p.109-112, 2014. http://dx.doi.org/10.1590/S1413-70542014000200001.

Guo, Z.; Zhang, Y.; Zhao, J.; Shi, Y.; Yu, Z. Nitrogen use by winter wheat and changes in soil nitrate nitrogen levels with supplemental irrigation based on measurement of moisture content in various soil layers. Field Crops Research, v.164, p.117-125, 2014. http:// doi.org/10.1016/j.fcr.2014.05.016.

Halvorson, A. D.; Snyder, C. S.; Blaylock, A. D.; Grosso, S. J. del. Enhanced efficiency nitrogen fertilizers: Potential role in nitrous oxide emission mitigation. Agronomy Journal, v.106, p.715-722, 2014. http://dx.doi.org/10.2134/agronj2013.0081.

Li, J.; Shi, Y.; Luo, J.; Zaman, M.; Houlbrooke, D. Use of nitrogen process inhibitors for reducing gaseous nitrogen losses from land-applied farm effluents. Biology and Fertility of Soils, v.50, p.133-145, 2014. http://doi.org/10.1007/s00374-013-0842-2

Rochette, P.; Macdonald, J. D.; Angers, D. A. Banding of urea increased ammonia volatilization in a dry acidic soil. Journal of Environmental Quality, v.38, p.1383-1390, 2009. http://doi. org/10.2134/jeq2008.0295
Sanz-Cobeña, A.; Sánchez-Martín, L.; García-Torres, L.; Vallejo, A. Gaseous emissions of $\mathrm{N}_{2} \mathrm{O}$ and $\mathrm{NO}$ and $\mathrm{NO}_{3}{ }^{-}$leaching from urea applied with urease and nitrification inhibitors to a maize (Zea mays) crop. Agriculture, Ecosystems \& Environment, v.149, p.64-73, 2012. https://doi.org/10.1016/j.agee.2011.12.016

Singh, J.; Kunhikrishnan, A.; Bolan, N. S.; Saggar, S. Impact of urease inhibitor on ammonia and nitrous oxide emissions from temperate pasture soil cores receiving urea fertilizer and cattle urine. Science of The Total Environment, v.465, p.56-63, 2013. https://doi.org/10.1016/j.scitotenv.2013.02.018

Tasca, F. A.; Ernani, P. R.; Rogeri, D. A.; Gatiboni, L. C.; Cassol, P. C. Volatilização de amônia do solo após a aplicação de ureia convencional ou com inibidor da urease. Revista Brasileira de Ciência do Solo, v.35, p.493-502, 2011. https://doi.org/10.1590/ S0100-06832011000200018

Tedesco, M. J.; Gianello, C.; Bissani, C. A.; Bohnen, H.; Volkweiss, S. J. Análise de solo, plantas e outros materiais. 2.ed. Porto Alegre, Universidade Federal do Rio Grande do Sul, 1995. 174p. Boletim Técnico, 5

Tian, Z.; Wang, J. J.; Liu, S.; Zhang, Z.; Dodla, S. K.; Myers, G. Effects of coated urea and urease and nitrification inhibitors on ammonia and greenhouse gas emissions from a subtropical cotton field of the Mississippi delta region. Science of the Total Environment, v.533, p.329-338, 2015. http://doi.org/10.1016/j. scitotenv.2015.06.147.

Zaman, M.; Blennerhassett, J. D. Effects of the different rates of urease and nitrification inhibitors on gaseous emissions of ammonia and nitrous oxide, nitrate leaching and pasture production from urine patches in an intensive grazed pasture system. Agriculture, Ecosystems and Environment, v.136, p.236-246, 2010. https://doi. org/10.1016/j.agee.2009.07.010

Zhang, M.; Fan, C. H.; Li, Q. L.; Li, B.; Zhu, Y. Y.; Xiong, Q. Z. A 2-yr field assessment of the effects of chemical and biological nitrification inhibitors on nitrous oxide emissions and nitrogen use efficiency in an intensively managed vegetable cropping system. Agriculture, Ecosystems and Environment, v.201, p.43-50, 2015. https://doi.org/10.1016/j.agee.2014.12.003 